\title{
高齢者専用賃貸住宅におけるサービス附帯と居住モデルに関する研究 ANALYSIS OF THE TRENDS OF HOUSING FOR THE ELDERLY FROM THE PERSPECTIVE OF ATTENDANT SERVICE AND RESIDENCE MODEL
}

\author{
佐 藤 栄 治*, 井上由起子**, 藤井 賢一郎*** \\ Eiji SATOH, Yukiko INOUE and Kenichirou FUJII
}

\begin{abstract}
Dwellings for the elderly may be classified into three types: one's own home, housing for the elderly, and nursing home, in which the housing for the elderly are said to be least developed. However, looking ahead, it is expected that the number of people who move to housing for the elderly will grow resulting from the increase in elderly population and the change in household composition. The object of this study is to obtain insight into high quality housing for the elderly. On that purpose, analyses were conducted using the following two methods:

1. Understanding of the nation-wide quantity of developed housing for the elderly,

2. Analysis of the trends of development of housing for the elderly from the perspective of architectural characteristics, user identification and attendant circumstances of relative services.
\end{abstract}

Keywords: rental housing exclusively for the elderly, attendant circumstances of relative services, residence model 高齢者専用賃貸住宅，サービス附帯，居住モデル

\section{1 背景と目的}

高歯期の居住の場は自宅，高齢者住宅，施設の 3 つに分類するこ とができる，施設の特徵は住居，食事，日常生活支援，介護をパッ ケージとして提供することで，認知症を含めた中重度の高齢者の生 活を 24 時間 365 日にわたって支えることにある。これに対し高齢 者住宅は, 安否確認, 緊急時対応などの基本サービスを備えること で，不安や困難を軽減させ，安心して自立生活を続けられるような 仕組みの住居を指す。一般的には，虚弱から中程度までを支えるも のとして認識されているが，サービス附帯の仕組みによっては，施 設の代替機能として整備することも可能である。

対高齢者人口でみる高齢者住宅の整備割合は，日本 $0.9 \%$ （シル バーハウジング, 高齢者専用賃貸住宅（以下，高専賃), 健康型有料 老人ホーム, 軽費老人ホーム等） ${ }^{1}$ ），スウェーデン $4.2 \%{ }^{2)}$, デン マーク $8.1 \%^{3}{ }^{3}$, 英国 $8.0 \%{ }^{4)}$ ，米国 2.2\% ${ }^{5 ）}$ となっている. 住宅 政策が異なる国々を一概に比較することはできないが，我が国の整 備量は際立って少ない，今後我が国では，都市部を中心に高齢者住 宅のニーズは増えると言われている ${ }^{6)}$ ，その背景には，団塊の世代 が一斉に高齢化を迎えて高齢者人口が 2040 年に概ねピークの 3,850 万人に達すること, 単身高齢者や高龄のみ世帯の増加が著しいこと, 単身高齢者の $35 \%$ が賃貸住宅に住んでいること，公的賃貸住宅にお
ける居住者の高齢化が進行していること, 施設が中重度者向けに収 斂してゆくためには自立〜軽度者向けの住まいを確保する必要性が 高じること，などが挙げられる。

我が国の高齢者住宅の整備量は，シルバーハウジング : 2.2 万戸, 高専賃 : 2.5 万戸, 高齢者優良賃貸住宅 (以下, 高優賃) $: 1.2$ 万戸 である注 1 ．なかでも近年制度的な拡充が行われているのは高専賃 であるが，市町村等の建設補助や家賃補助がある高優賃を除くと， 高専顀には質を誘導する基準が明確には定められていないうえに, さまざまな運営形態があり, 質的検証と今後の整備方針の策定に資 する知見の蓄積が求められている（なお高専顀は 2008 年 5 月の高 齢者居住安定確保法の改正を受け，登録基準が設けられた）。

高専賃制度は施行されて間もないこともあり注 2), 先行研究の蓄 積が多いとは言い難い. 小野 ${ }^{7)}$ は首都圈の高専賃整備状況を把握し, 松川ら ${ }^{8)}$ は中国・四国・九州地方の整備状況を把握している。石 井 $^{9)}$ のように数力所の高専賃に対象を絞り，住環境の質や付加する サービスを検討したもの, 熊澤ら ${ }^{10)}$ のように転用における整備手 法の方策を論じたものもある. 不動産 ${ }^{11)}$ や経済 ${ }^{12)}$ の分野での分 析・事例紹介もある。いずれも, 地域や対象を限ったものではあるが, 多くの知見を提供している. 今後は, 全国的な整備動向を把握した うえで, 利用者像やサービス附帯の状況を明らかにし, 検討を加え
* 国立保健医療科学院施設科学部 協力研究員 · 博士 (丁学)

** 国立保健医療科学院施設科学部 施設環境評価室長・博士(工学)

*** 日本社会事業大学大学院福祉マネジメント研究科 准教授·博士 (保健学)
Researcher, Department of Facility Sciences, National Institute of Public Health, Dr. Eng. Section Chief, Department of Facility Sciences, National Institute of Public Health, Dr. Eng.

Assoc. Prof., Graduate School of Social Service Management, Japan College of Social Work, Dr. H. Sc. 
ることが必要であろう。そこで，全国の高専賃を対象に，全国的な 整備状況を把握したうえで，建築特性，利用者像，サービス附帯の 状況から現在整備されている高専顀の概観を明らかにし，今後の良 質な高秢者住宅整備に向けた知見を得ることを目的に研究を実施し た.

なお，本研究は高専顀に関する幅広い課題を取り扱っている，全 国的な整備状況と設備別・地域別・運営主体別の家賃特性，ならび に市場家賃との関連については，既報13)にて報告している，本稿 では，高専賃に関する基礎的な情報として，既報の内容を本稿の理 解を深めるために 3 章，4 章の一部に再揭する。

\section{2 研究概要と調査手法}

2. 1 本研究で扱う高齢者住宅の範囲

本研究で扱う高齢者住宅は，高専賃と高優賃の 2 種とする.

高専顀は 2005 年の高齢者居住安定確保法に基づき，各都道府県 の指定登録機関に登録された高齢者円滑入居賃貸住宅のうち，もっ ぱら高齢者または同居の配偶者を賃借人としたうえで一定の基準を 満たした住宅を指す注 ${ }^{3)}$. 2009 年 8 月現在で 1,411 件，36,973 戸 が登録されている．高優賃は，高専賃よりもバリアフリーに関する 基準が上乗せされ，都道府県知事等の認定を受けたものを指す。賃 借人を収入分位 $80 \%$ 以下に限定した場合には整備費補助があり, 収 入分位 $40 \%$ 以下の世帯に対して家賃減額補助がある注 4). 2009 年 3 月末現在で 474 件， 12,145 戸が整備されている.概念的には高優 賃は高専顀に内包されているが，高専賃登録をしていない高優賃が 多数存在している.

これら高歯者住宅では，どのようなサービスを住宅に附帯させる かについて様々な選択肢があり，その組み合わせ，提供方法（介護 保険・介護保険外), 価格は自由に設定できる .

\section{2 調査概要}

調査の枠組みを表 1 に示す。下記にその詳細を記す。

(1)高齢者住宅に関するデータ収集

$\mathrm{a}$ ：高歯者住宅財団登録データ分析調査, $\mathrm{b}$ ：高専賃アンケート調 査の二種類を実施した。収集デー夕は表 2 に示すとおり.

\section{a：高齢者住宅財団登録デー夕収集}

高齢者住宅財団に登録されている高専賃（含む高優賃）のデー夕 （以下, 財団登録データ）を用い, 表 2 に示すデー夕を収集した（2008 年 6 月末時点の登録データ). この時点での登録事業所数（件）と 登録整備戸数（戸）は 885 件，21,377戸で，このうち一時金と前 払い家顀の合計額が 300 万円以上の 21 件については，賃貸住宅の 本来の趣旨とは異なると判断し，分析対象から除外した注 ${ }^{5)}$ 。この 結果, 分析デー夕数は 864 件, 20,643 戸 (うち, 高優賃 240 件, 5,679 戸)となった（図 1 ).

$b$ ：高専賃アンケート調査データ収集

2008 年 6 月末時点で高齢者住宅財団に登録されている高専顀に 対して，アンケート調査を実施した注6)．調査は高齢者住宅財団が 実施し, 得られた結果を本研究用に再分析した。分析対象配布数 864 票，回収 399 票（回収率，46.2\%) であり，399 票のうち 211 票から平面図の提供を受けた.

(2)各種統計データ収集

高齢者住宅の整備状況を，都道府県などのエリア単位で各種統計
デー夕と比較分析するために，デー夕収集を実施した。収集デー夕 は, 都道府県別の高歯者人口・高齢化率・持ち家率, 都道府県別の 高齢者施設定員数である。

\section{3 分析内容}

\section{(1)高齢者住宅の整備状況}

財団登録データをもとに高齢者住宅の全国的な整備概要を把握 し, 整備量と高齢者数・高齢化率・施設整備量・持ち家率との関係 の有無を検討した。

(2)サービス附帯・利用者像・供給主体・建築の関係性の把握

高専賃アンケート調査結果をもとに，個人空間と共用空間の整備 状況から居住モデルを抽出し, 居住モデルと運営主体・想定利用者 像・併設事業所数の相関関係を分析した。

\section{3 全国的な整備状況}

財団登録デー夕をもとに，高専賃・高優賃別に都道府県ごとの整 備状況を把握し, 整備実数・高齢者人口 1,000 人対整備割合注 7$)$ と 各種統計デー夕との相関係数を算出したものが表 3 である。都道府 県別の整備実数と各種統計デー夕の実数（表 3 の左側）とは, 相関 係数が高く一定程度の相関関係が見られる。しかし整備割合と 65 歳人口に対する各種統計比率（表 3 の右側）では，相関係数が低く 相関関係は見られない.

高齢者施設整備量については要介護 $2 \sim 5$ の高齢者数を母数とし

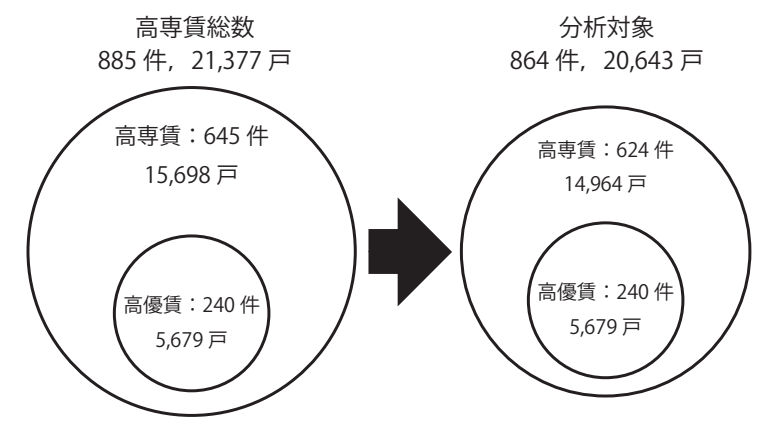

図 1 分析対象のデー夕数

表 1 調查の概要

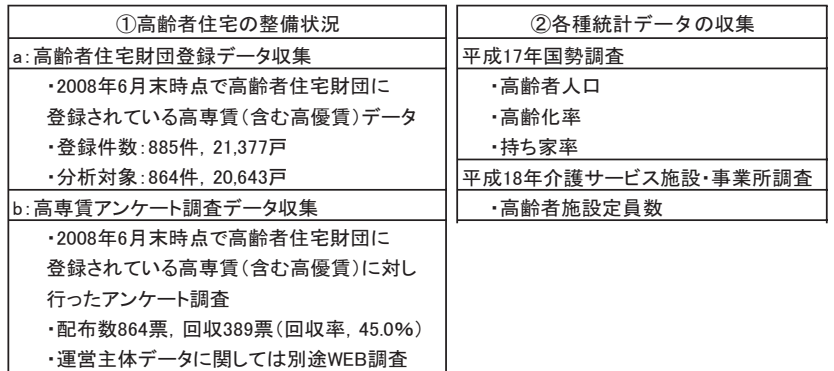

表2 項目一覧

\begin{tabular}{|c|c|c|c|c|c|c|c|}
\hline \multicolumn{4}{|c|}{ 財団登録データ: 864件 } & \multicolumn{4}{|c|}{ アンケート調査: 399件, 内図面あり:211件 } \\
\hline \multicolumn{2}{|c|}{$\begin{array}{c}\text { 項目 } \\
\text { 物件立地 }\end{array}$} & \multicolumn{2}{|c|}{ 内容 } & \multirow{2}{*}{\multicolumn{2}{|c|}{$\begin{array}{c}\text { 項目 } \\
\text { 運営主体 }\end{array}$}} & \multirow{2}{*}{\multicolumn{2}{|c|}{$\begin{array}{c}\text { 内容 } \\
\text { 法人種別 }\end{array}$}} \\
\hline & \multicolumn{2}{|l|}{ 都道府県 } & & & & \\
\hline \multirow{2}{*}{\multicolumn{2}{|c|}{ 建物と住宅費用の概要 }} & 戸数 & 住戸面積下限 & \multicolumn{2}{|c|}{ 建物の概要 } & 戸数 & 住戸面積 \\
\hline & & \multicolumn{2}{|c|}{ 家貸＋共益費下限 } & \multirow{4}{*}{ 空間構成 } & \multirow[t]{2}{*}{ 個人空間 } & 台所 & 便所 \\
\hline \multirow{4}{*}{ 空間構成 } & \multirow{2}{*}{ 個人空間 } & 台所 & 便所 & & & 洗面 & 浴室 \\
\hline & & 洗面 & 浴室 & & \multirow[t]{2}{*}{ 共用空間 } & 食堂 & 台所 \\
\hline & \multirow{2}{*}{ 共用空間 } & 食堂 & 台所 & & & 浴室 & \\
\hline & & 浴室 & & \multirow{2}{*}{\multicolumn{2}{|c|}{ 併設機能 }} & \multirow{2}{*}{\multicolumn{2}{|c|}{$\begin{array}{l}\text { 介護保険に関わるサービス } \\
\text { 医療保健に閩わるサービーー }\end{array}$}} \\
\hline \multirow{3}{*}{\multicolumn{2}{|c|}{ サービス }} & 食事 & 介護の有無 & & & & \\
\hline & & 洗濯·掃除 & 安否確認 & \multicolumn{2}{|c|}{ 保険外サービス } & 見守り & 食事 \\
\hline & & 健康管理 & & \multirow{2}{*}{\multicolumn{2}{|c|}{ 利用者 }} & 年齢 & 要介護度 \\
\hline & & & & & & 入居要件 & 継続程度 \\
\hline
\end{tabular}


た参酶標準があるが，高齢者住宅整備量についてはそのような基準 は存在しない. 高齢者施設整備実数と各種統計デー夕の実数には相 関係数が高いものの, 整備実数が各種統計デー夕の実数に対して極 小であること，また整備割合では相関が見られないことから，現時 点では高齢者住宅の整備状況は各種統計デー夕との関連性が見られ ないと判断できる.

\section{4 家賃の状況}

財団登録デー夕をもとに家賃に関して分析を行う。用いた家賃の 值は当該高専顀の下限家賃であり, 同様に個人空間の広さは当該高 専賃貸の下限面積である。財団登録デー夕における家顀とは「家顀 及び共益費の概算額」を指すが, 殆どの高専賃は見守りサービス（緊 急時対応, 安否確認, 相談など）を附帯させているため, 家貨十共 益費十基礎サービス費で構成されている．共益費は建物の維持管理 を，基礎サービス費は利用者の見守りを担うものと解釈されている が，共益費に見守りに該当する基礎サービス費が組み込まれている 場合もあるので, 留意が必要である注 8 )

また，高優顀は近傍の市場家顀をもとに設定することが明記され ているので, 図 3 〜図 5 は高優賃を除いた高専賃のみを対象とした.

\section{1 個人空間の広さと家賃の概要}

図 2 に個人空間の広さ，家賃，家賃の $\mathrm{m}^{2}$ 単価を示す注 9), 10).

個人空間の広さは高専賃が $18 \sim 25$ m近辺で, 高優賃が 30 $40 \mathrm{~m}^{2}$ 近辺で整備されている. 平均值は高専賃 $22.3 \mathrm{~m}^{2}$, 高優賃 35.9

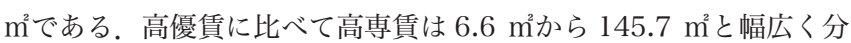
布していることに特徴がある.

家貨の平均值は高専賃 73,104 円, 高優賃 66,990 円となっている. 高優賃は高専賃より個人空間が広いにもかかわらず，建設補助があ ることも影響し，家賃が低く設定されている．個人空間の広さと同 様に，高専賃の家賃は 15,000 円〜 390,000 円と高優顀に比べて幅 がある。なお，高優賃では収入分位 $40 \%$ 以下に対して減額補助があ るので，実際の家賃はさらに低くなる.

家賃の平米単価の平均は高専賃 3,792 円 $/ \mathrm{m}^{2}$ ，高優賃 1,981 円 $/$ $\mathrm{m}^{2}$ である. 高専賃は高優賃のおおよそ 2 倍の単価を示している，個 人空間の広さや家賃と同様に，高専賃の平米単価は 274 円 $/ \mathrm{m}^{2} \sim$ 19,628 円 $/ \mathrm{m}^{2}$ と高優賃に比べて幅が広い.

以上，空間が充実しているにもかかわらず，高優債の家賃は高専 賃の家兵より低く設定されていることが判明した．高専賃は中堅所 得者層を主対象としているのに対し, 高優顀は低所得者層を主対象 としているためと推察される。これと同じ関係は, 公営住宅と民間 賃貸住宅，個室ユニット型特別養護老人ホームと有料老人ホームの 間にも読み取れる。高優賃, 公営住宅, 個室ユニット型特別養護老 人ホームは低所得者向けであるが故に行政の強い関与によって市場 とは異なるメカニズムで供給され, 結果として高専顀, 民間賃貸住宅, 有料老人ホームよりも空間の充実度に比べて家看が低く設定されて いる.

\section{2 個人空間の広さと家賃の相関}

図 3 に個人空間の広さと家賃の関係図を示す.

通常の賃貸住宅市場では，家賃は個人空間の充実度によって異な るとの考えが支配的である。しかし図 3 でも明らかなように，個人 空間の広さと家顀との間には単純な相関関係は見られなかった（R $\left.{ }^{2}=0.02\right)$.さらに，個人空間広さを設置基準を踏まえて 4 つに区
表 3 整備状況と各種統計データとの相関関係

\begin{tabular}{|c|c|c|c|c|}
\hline 分類 & 65歳以上実数 & 整備実数との相関係数 & 65歳人口に対する比率 & 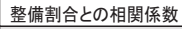 \\
\hline 人口関連 & \begin{tabular}{||l|l}
$口$ \\
総世帯数 \\
単身世帯数 \\
夫婦のみ世帯数
\end{tabular} & $\begin{array}{l}0.749 \\
0.734 \\
0.692 \\
0.767 \\
\end{array}$ & $\mid$\begin{tabular}{|l|l|l} 
齢化率 \\
\end{tabular} & -0.132 \\
\hline 住居の所有形態 & \begin{tabular}{||l}
$\mid$ 持ち家世帯数 \\
公的賃貸世帯数 \\
民間賃貸世帯数
\end{tabular} & $\begin{array}{l}0.735 \\
0.646 \\
0.725\end{array}$ & 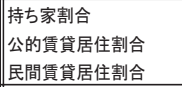 & $\begin{array}{c}0.083 \\
-0.144 \\
-0.019 \\
\end{array}$ \\
\hline 高龄者施設 & ||高齢者施設定員数 & 0.811 & || 高齢者施設整備割合 & 0.052 \\
\hline
\end{tabular}
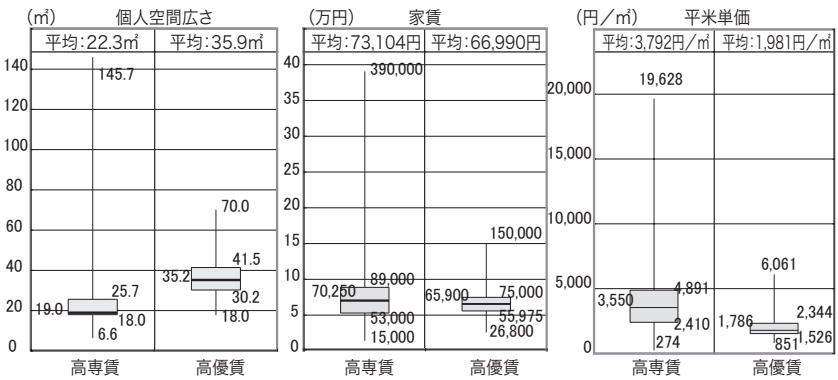

図2 個人空間の広さ $\left(\mathrm{m}^{2}\right)$, 家貨 $($ 円 $)$, 平米単価 $\left(\right.$ 円 $\left./ \mathrm{m}^{2}\right)$

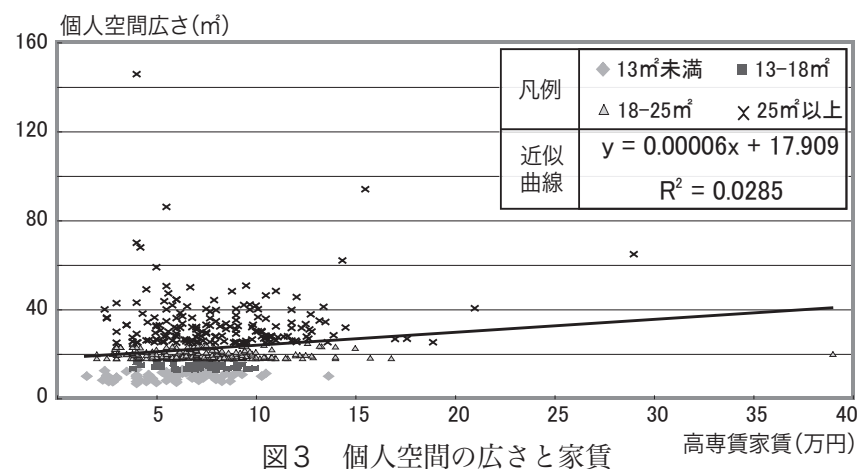

\begin{tabular}{|c|c|c|c|c|}
\hline 件数 & 81 件 & 58件 & 279件 & 175件 \\
\hline 平均 & 57,638円 & 70,467円 & 71,622円 & 83,446円 \\
\hline 標準偏差 & 23,251円 & 15,089円 & 33,316円 & 36,289円 \\
\hline （万円） & & & 390,000 & \\
\hline 30 & & & & 290,000 \\
\hline \multicolumn{5}{|l|}{20} \\
\hline \multirow[b]{2}{*}{10} & 136,500 & 99,394 & & 103.500 \\
\hline & \begin{tabular}{|l|l|}
60,000 & 71,250 \\
\end{tabular} & \begin{tabular}{|l|l|l|}
74,000 & 19,125 \\
\end{tabular} & 70,000 & 79,000 \\
\hline \multirow{2}{*}{0} & $\begin{array}{r}40,000 \\
15,000\end{array}$ & $\begin{array}{l}59,250 \\
38,000 \\
\end{array}$ & $\begin{array}{l}50,000 \\
20,000\end{array}$ & $\begin{array}{l}58,000 \\
24,000\end{array}$ \\
\hline & 13m²末満 & $13 \mathrm{~m}^{2} \sim 18 \mathrm{~m}^{2}$ & $-25 m$ & 以上 \\
\hline
\end{tabular}

図4 設置基準ごとの家賃の状況

\begin{tabular}{|c|c|c|c|c|}
\hline 件数 & 86件 & 508件 & 194件 & 175件 \\
\hline 平均 & 64,816円 & 74,472円 & 68,235円 & 78,060円 \\
\hline 標準偏差 & 31,052円 & 32,828円 & 36,970円 & 26,947円 \\
\hline \multicolumn{5}{|l|}{ （万円） } \\
\hline \multirow[t]{3}{*}{30} & & & & \\
\hline & & & \multirow{2}{*}{290,000} & \\
\hline & & & & 210,000 \\
\hline 20 & 189,000 & & & \\
\hline \multirow[t]{2}{*}{10} & & 90,000 & \multirow[t]{2}{*}{85,000} & 90,000 \\
\hline & \begin{tabular}{|l|l}
55,650 & 70,000 \\
\end{tabular} & $7 1 \longdiv { 2 5 0 }$ & & 74,200 \\
\hline \multirow{2}{*}{0} & $\begin{array}{l}42,000 \\
24,000\end{array}$ & $\begin{array}{l}55,000 \\
15,000\end{array}$ & $\begin{array}{r}48,000 \\
26,800\end{array}$ & \begin{tabular}{|l}
60,000 \\
20,000
\end{tabular} \\
\hline & 共有空間なし & 共有空間あり & 併設事業所無し & 併設事業所有り \\
\hline
\end{tabular}

図 5 共用空間の有無，併設事業所の有無と家顀 


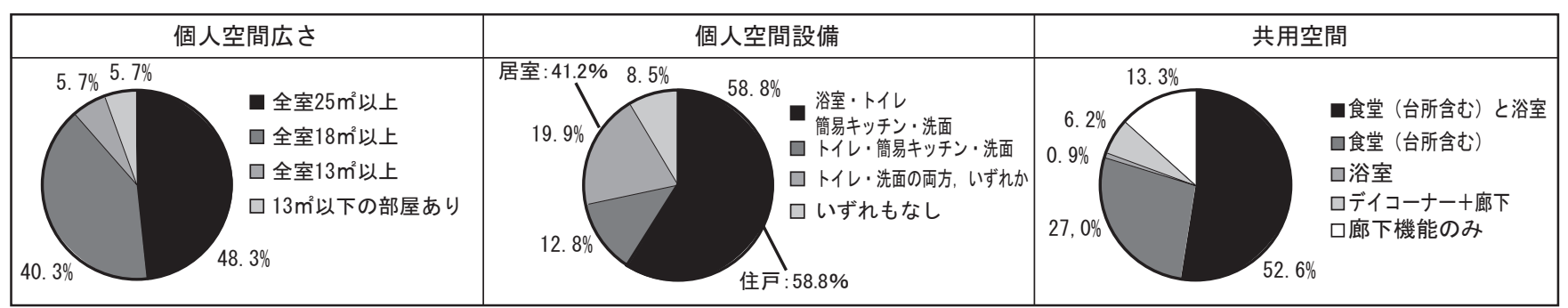

図 6 個人空間広さ, 個人空間設備, 共用空間の回答割合

切り, 家顀の状況を把握したところ (図 4), 個人空間が広くなるに つれ平均家賃が上昇する傾向が見られたものの, 標準偏差や中央値 からは統計学的には明確な相関が見られないことが判明した。

\section{3 設備と家賃}

共用食堂の有無，併設事業所（同一建物）の有無と家顀の関係性 を分析した注 11) (図 5 ). 結果として, 共用食堂の有無では, 「有り」 の方が平均家顀で 10,000 円程度高く設定されていた。 また併設事 業所の有無では, 「有り」の方が平均家賃で 10,000 円程度高く設定 されていた，標準偏差や中央值など統計学的にも家顀と相関関係が あることが判明した。 以上より, 建物の個人空間広さに加えて, 共 用食堂の有無や併設事業所の有無も家賃に影響を与えていることが 分かった.

5 平面計画, サービス附帯, 利用者像, 供給主体別にみた特徵 アンケート調査結果をもとに平面計画, サービス附帯, 利用者像, 供給主体の特徵を把握する。

\section{1 平面計画 $(N=211)$ (図6)}

平面図の提供を受けた 211 票の分析結果を示す.

(1)個人空間の広さ

「全室 $25 \mathrm{~m}^{2}$ 以上」が $48.3 \%$ ，「全室 $18 \mathrm{~m}^{2}$ 以上」が $40.3 \%$ ，「全 室 $13 \mathrm{~m}^{2}$ 以上」が 5.7\%,「13 m²下の部屋あり」が 5.7\%であった。 2009 年の高齢者居住安定確保法の改正により, 高専顀の個人空間 の広さは $25 \mathrm{~m}^{2}$ 以上 (十分な共用スペースがある場合には $18 \mathrm{~m}^{2}$ 以上) と基準が設けられたが，これに該当しないものが $11.4 \%$ 存在する. (2)個人空間の設備

食事・更衣・排泄・整容・入浴などの生活行為を行ううえで必 要不可欠な「洗面, トイレ, 簡易キッチン, 浴室」の諸設備を全て 有する個人空間 (以下，住戸）は $58.8 \%$ であった。これらの諸設 備のいずれかを欠くと共用部で日々の生活が生じ，個人空間で日々 の生活が完結しなくなる。このような個人空間（以下，居室）が 41.2\%であった。 個室が住戸レベルか居室レベルのいずれである かは，事業者が想定する入居時の利用者像に左右されると考えられ る，自立あるいは虚弱程度で入居する場合には食事・更衣・排泄・ 整容・入浴なぞの生活行為を個人空間内で完結できる空間すなわち 住戸が必要だが, 中重度者向け施設での生活実態から, 中重度程度 で入居する場合には介護の必要性から食事や入浴は共用空間を利用 するのもやむを得ない＝個人空間に浴室や簡易キッチンがなくても やむを得ない（中重度者向け施設の個室はその殆どが居室レベルで ある）との認識があるためである.

(3)共用空間

「食堂，浴室」の双方を備えているものは $52.6 \%$, 「食堂」のみを

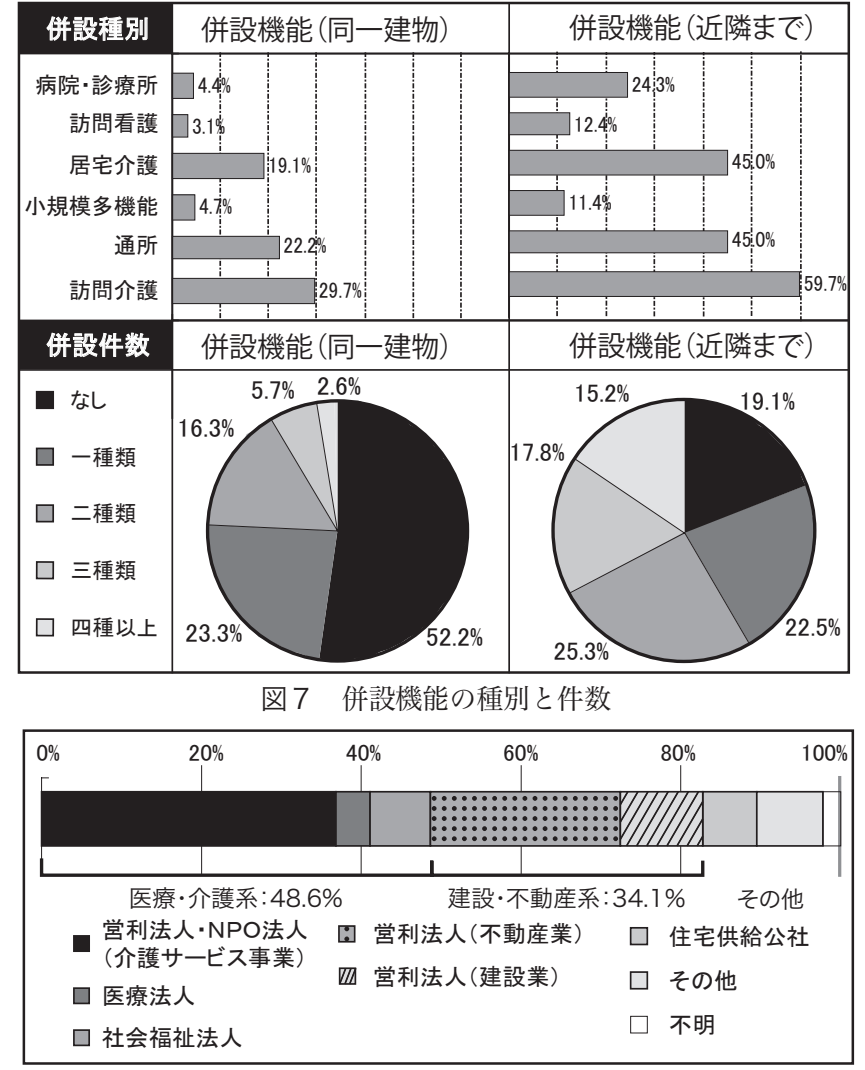

図8 運営主体

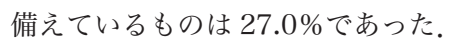

食堂や浴室といつた共用空間の有無は, 事業者が想定する利用者 の継続居住方針に左右されるものと考元られる.中重度になった場 合に, 介助を受けつつ継続居住できる住宅であるか, 退去しなけれ ばならない住宅であるかといったことである. 即ち, 要介護度が進 むと食事や入浴に介助が必要となり, 個人空間内で食事介助や入浴 介助を行うことは困難で, 共用の食堂や浴室が必要との認識がある ためである (中重度者向けの施設では共用の食堂や浴室が必置義務 となっている) .

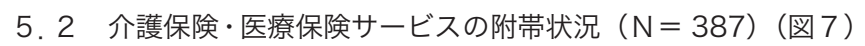

一般には, 訪問介護, 通所, 小規模多機能のいずれかを併設させ ることで, 介護が必要な高齢者への介護サービスが提供しやすくな ると言われている。

\section{(1)併設機能の種類}

同一建物への併設機能をみると訪問介護 $29.7 \%$, 通所 $22.2 \%$, 小規模多機能 $4.7 \%$ と, 介護系サービスの割合が高い.これに対し， 医療系サービスは病院・診療所 $4.4 \%$, 訪問看護 $3.1 \%$ と低い. 近隣 までを含むと病院・診療所 $24.3 \%$, 訪問看護 $12.4 \%$ と高くなる. 


\section{(2)併設件数}

同一建物への併設件数は「なし」が $52.2 \%$ と半数近くを占め，次 いで「1 種類」 $23.3 \%$ ，「2 種類」 $16.3 \%$ と続く．同一建物に加え て近隣までを含めると，「2 種類」が $25.3 \%$ と最も多く，「1 種類」 $22.5 \%$ ，「なし」19.1\%と続く.

5.3 運営主体（ $N=399 ）$ (図 8)

運営主体については医療・介護系が $48.6 \%$ （介護サービス事業系 が $37.0 \%$, 社会福祉法人が $7.5 \%$, 医療法人が $4.3 \%)$, 不動産・建 設系が 34.1％（不動産業が 23.8\%，建設業が 10.3\%）となってい る注 12).

5.4 利用者像 $(N=399)$ （図 9)

年齢構成, 入居要件, 継続居住要件について回答を寄せた 399 票 の分析結果を示す.

(1)年齢構成

利用者の年齢は，「〜 74 歳まで」が $12.8 \%, 「 〜 79$ 歳まで」が $26.1 \%$ ，「〜 84 歳まで」が $35.1 \%$,「85 歳以上」が $8.0 \%$ となった。 75 歳以上の後期高齢者が $69.2 \%$ と多数を占める.

(2)入居要件

入居要件は,「自立のみ」が $18.0 \%$,「要介護度 2 まで」が $22.6 \%$,「要 介護度 3 以上も可」が $53.4 \%$ となった。必ずしも軽度者を入居対象 としてはいないことがわかる.

(3)継続居住要件

継続居住可能な要介護度の目安は，「要介護度 2 まで」が $19.3 \%$, 「要介護度 3 まで」が $15.8 \%$,「要介護度 4 以上も可」が $21.3 \%$,「夕ー ミナルまで」が $30.6 \%$ となった。 ターミナルまでとの回答が多いが, 調査時期が高専賃の整備初期段階にあるため, 事実よりも事業目標 に基づく点が多分にあると推察されるので，留意が必要である.

\section{6 居住モデルの抽出と特徵}

6.1 居住モデルの抽出

一般に, 要介護度が高くなると日常生活において介助を必要とす るため, 個人空間での諸設備（浴室，台所）の利用頻度が下がり， 共用空間の諸設備 (浴室, 食堂) の利用頻度が高くなると考えられる. 先行研究も同様の指摘をしており, 例えば, 石井 $\left.{ }^{9}\right)$ は, 住居型（住 戸内専用設備：台所，便所，収納，浴室）と居室型（同：収納）の 高専賃における入居者の属性や入居経緯等を調査し, 前者では自立 度の高い入居者が多いこと, 後者では全入居者が要介護認定を受け ていたことを報告している，松川ら ${ }^{8)}$ は，要支援以上の入居者の割 合はシェアード型（住戸部分に台所，便所，浴室のいずれかが欠け ており住戸内で生活が完結しない) では 95\%超, コレクティブ型（住 戸内に台所，便所，浴室がそろい，かつ共用空間に台所がある）で は35\%であることを報告している.

そこで本稿においても, 個人空間と共用空間の関係性に着目し, 以下の 3 つを居住モデルとして抽出した.

「居室十共用食堂」モデル：個人空間内で日常の基本的な生活行為が 完結できないが，共用食堂がある，浴室や台所が個室にないことか ら入居時点で生活の一部を共用空間に依存する身体状況すなわち要 介護レベルで入居し, 施設ケアが必要になっても住み続けることが 可能な利用者像と想定される.

「住戸+共用食堂」モデル：個人空間内で日常の基本的な生活行為が

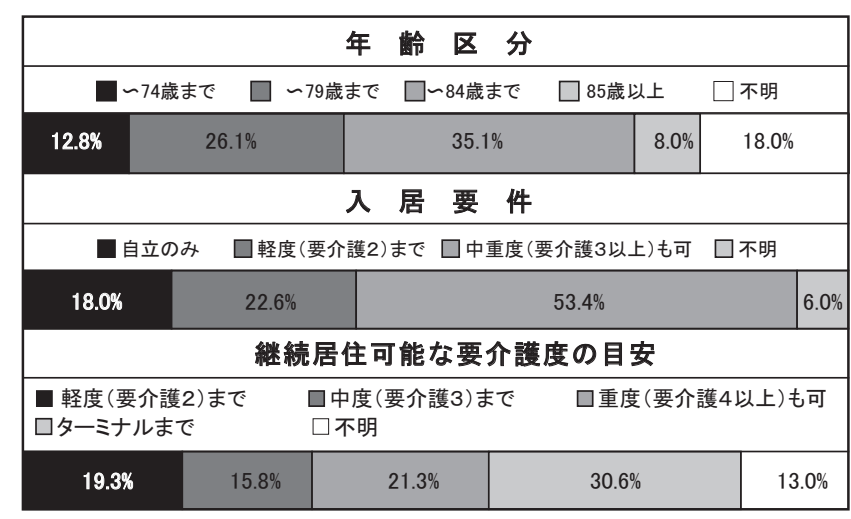

図 9 年齢区分, 入居要件, 継続居住可能な要介護度の目安の割合

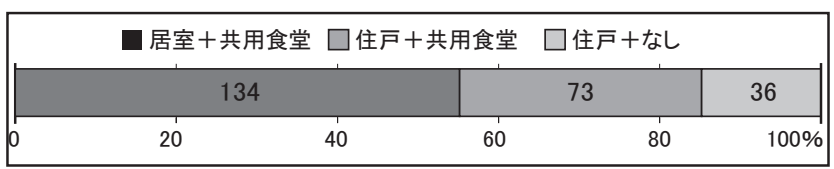

図 10 居住モデルの割合

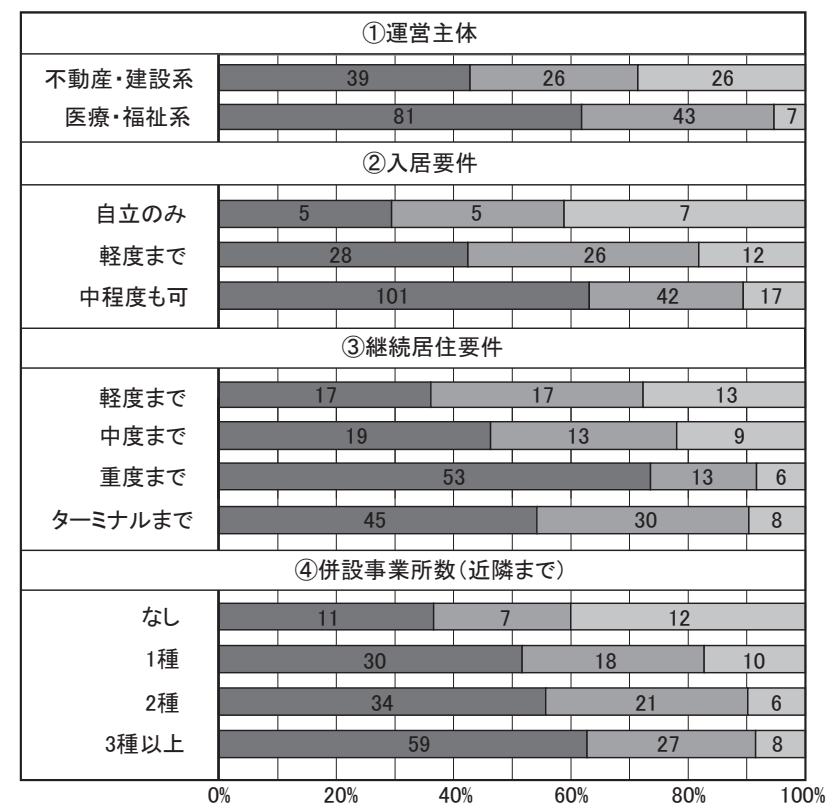

口居室十共同食堂 $\square$ 住戸十共同食堂 $\square$ 住戸十なし（整数は件数を表す）

図 11 居住モデルの特性

完結でき, かつ共用食堂もある. 自立レベルから入居可能で, 施設 ケアが必要になっても住み続けられる利用者像といえる.

「住戸十食堂なし」モデル：個人空間内で日常の基本的な生活行為が 完結できるが, 共用食堂はない. 自立レベルから入居し可能で, 食 事の支援が必要になった場合には退去する利用者像と想定される.

本節では, 運営主体, 入居要件, 継続居住要件, 併設事業所数の 把握できた 243 件について分析を行った。 243 件の内訳は, 「居室 十共用食堂」モデルが $55.1 \%$ (134 件), 「住戸十共用食堂」モデル が 30.0\% (73 件), 「住戸十食堂なし」モデルが 14.8\% (36 件)であつ た (図 10).

6.2 居住モデルの特性（図 11)

(1)居住モデルと運営主体

不動産・建設系は「住戸十共用食堂」や「住戸十なし」など「住戸」 を整備するものが多い。これに対し医療・介護系は「居室十共用食堂」 
表 4 因子分析の結果

\begin{tabular}{|c|c|c|c|c|c|}
\hline & 因子1 & 因子2 & 因子3 & 因子4 & 因子5 \\
\hline 名称 & $\begin{array}{c}\text { 保険外 } \\
\text { サービス }\end{array}$ & $\begin{array}{l}\text { 安否確認 } \\
\text { サービス }\end{array}$ & $\begin{array}{c}\text { 介護系 } \\
\text { サービス }\end{array}$ & $\begin{array}{c}\text { 医療系 } \\
\text { サー゙スス }\end{array}$ & 重度利用者 \\
\hline 保険外介護サービス & 0.8869 & 0.0380 & 0.0270 & 0.0274 & -0.0286 \\
\hline 生活支援サービス & 0.8833 & 0.0666 & -0.0361 & -0.0480 & -0.0035 \\
\hline 健康管理 & 0.7423 & 0.1707 & -0.0570 & 0.1421 & 0.0139 \\
\hline 食事提供 & 0.6715 & 0.0318 & -0.0651 & 0.0869 & 0.1153 \\
\hline 安否確認(昼) & 0.2083 & 0.9562 & 0.0072 & 0.0221 & 0.0466 \\
\hline 安否確認(夜) & 0.1606 & 0.8781 & -0.0068 & 0.0117 & 0.0361 \\
\hline 居宅介護支援 & -0.0567 & 0.0031 & 0.8310 & 0.1805 & 0.0582 \\
\hline 訪問介護 & -0.0740 & -0.0046 & 0.7109 & 0.0566 & 0.2028 \\
\hline 訪問看護 & 0.0838 & 0.0002 & 0.1960 & 0.7475 & -0.0602 \\
\hline 病院 & 0.0656 & 0.0386 & 0.0295 & 0.6488 & 0.0081 \\
\hline ターミナルまで対応 & 0.0242 & 0.0754 & 0.1049 & 0.0186 & 0.7658 \\
\hline 中重度でも入居可 & 0.0414 & -0.0083 & 0.1650 & -0.1066 & 0.5185 \\
\hline フロントサービス & 0.5732 & 0.2163 & -0.0041 & -0.0416 & -0.0506 \\
\hline 小規模多機能 & -0.0120 & 0.0083 & -0.0401 & 0.0797 & -0.0244 \\
\hline 通所 & -0.0050 & -0.1499 & 0.1431 & 0.3087 & -0.0718 \\
\hline
\end{tabular}

や「住戸十共用食堂」など「共用食堂」を整備するものが多い.

(2)居住モデルと想定利用者像

入居要件が「自立のみ」から「中重度も可」に移行するほど「居 室十共用食堂」の割合が増える。継続居住要件と居住モデルとの関 係をみると，「ターミナルまで」に移行するほど「居室十共用食堂」 や「住戸十共用食堂」など共用食堂を持つ割合が多くなる。

(3)居住モデルと併設事業所数

訪問介護，通所，小規模多機能，居宅介護支援，訪問看護，病院· 診療所の 6 種類の併設事業所数（近隣まで含む）と居住モデルをク ロス集計すると,併設件数が増えるにつれ「居室十共用食堂」や「住 戸十共用食堂」など共用食堂を持つ居住モデルが増える，共用食堂 と併設機能により，継続居住をサポートしていると考えられる。

\section{3 居住モデルと因子分析}

\section{(1)因子分析の概要}

3つの居住モデルにおける特徵を探索するため, 想定利用者像, 各種の附帯サービスの 15 項目で因子分析（重みづけのない最小 2 乗法）を行った。居住モデルはアンケート票からも確定できたので, 分析対象は高専賃アンケート調査で回収した 389 票のうち，欠損值 のある票を除いた 243 件である。分析の結果，固有值 0.5 以上とす ると因子が 5 つ認められた。回転後（コーティマックス法）の結果 は表 4 に示す通りである.

各因子に負荷量の高かった項目を解釈して，因子を命名した。第 1 因子は, 「介護保険外介護」「生活支援サービス」「食事の提供」「健 康管理」の 4 項目からなり『保険外サービス』と命名した。第 2 因 子は「安否確認 (昼)」「安否確認 (夜)」の2 項目からなり『安否確 認サービス』と,第 3 因子は「居宅介護支援事業所」「訪問介護事業所」 の 2 項目からなり『介護系サービス』と,第 4 因子は「訪問看護」「病 院」の 2 項目からなり『医療系サービス』と，第 5 因子は「中重度 も入居可」「ターミナルまで受け入れ」の 2 項目からなり『重度利用 者』と命名した。

(2)居住モデルと因子

各因子に含まれる因子得点を居住モデル別に算出し，図 12 に提 示した，因子得点のグループ平均をみると「居室十共用食堂」と「住 戸十共用食堂」はほぼ同じ因子得点である。「住戸十なし」はこれ ら二つの居住モデルと若干の差異があった（統計学的には差異はな い）. 共用食堂なしの「住戸十なし」は共用食堂ありの「居室＋共 用食堂」「住戸十共用食堂」に比べて, 重度利用者が少なく, 介護系

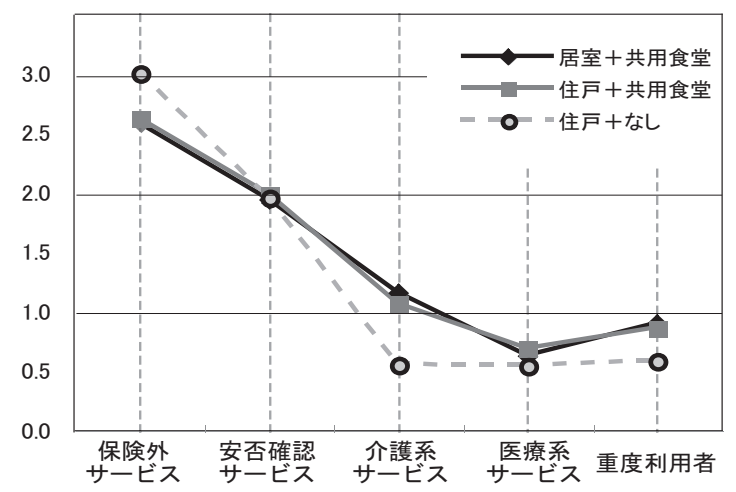

図 12 居住モデルと因子の関係

サービスの附帯が少なく，保険外サービスが多い傾向にあった．

\section{4 居住モデルと整備特性}

図 11 に示した居住モデルの特性ならびに図 12 に示した居住モデ ルと因子の関係から, 以下のような仮説ならびに考察が可能と考え る。

「居室＋共用食堂」と「住戸 + 共用食堂」の因子得点がほぼ同じ であったのは，介護保険の仕組みによるところが大きいと考える． 両者の共通点は継続居住が可能であることであり, 両者の相違点は 入居時点の身体状況にある.すなわち, 後者は前者よりも幅広い心 身状況に対応可能な建築である。しかしながら, 現行の介護保険制 度は心身状況を一定の範囲内に限定したほうが経営メリットが大 きいうえに, 運営マネジメントもしやすいため, 自立から重度まで 幅広い利用者像に対応する高齢者住宅というのは現実には多くはな い.「住戸十共用食堂」が包摂する建築としての可能性（自立期から 介護期までの継続居住が実現しやすい) を十分に活かせる状況にな いため,「住戸+共用食堂」と「居室＋共用食堂」は同じ因子得点 になったものと推察される。

一方，「住戸 + なし」は建築として共用食堂を必要とするような 中重度者には向いていないため, 軽度者中心となり, 見守りサービ スや食事や生活支援などの保険外サービスと, 地域に点在する事業 所から通常の在宅と同様に保険サービスをデリバリーすること（= 事業所を併設させなくても対応可能な利用者像）で対応しているも のと推察可能と考える.

このほかにも，事業計画段階において建築と利用者像との関係性 に混乱が生じていること, 併設機能である医療介護事業所が高専顀 のみならず地域の在宅をも対象にしていること, 併設介護事業所に て食事や入浴を済ますこと（たとえば，デイサービス，小規模多機 能など), なども, 居住モデルによって因子得点の傾向が大きな違い がなかった要因として推察される。

\section{7 まとめ}

本稿では，高専賃の整備状況を全国レベルで把握したうえで，平 面計画，利用者像，併設機能，運営主体の関係性を明らかにすると ともに，3つの居住モデルを提案し，居住モデルの特性を検討した. 本稿で得られた知見は以下のとおりである.

(1)家賃の状況

家賃補助や建設補助のある高優賃は, 高専賃よりもハードのス ペックがよいにも関わらず家顀は低く設定されていた。また，高優 顀を除いた高専賃について分析したところ, 個人空間の広さと家顀 
に相関関係が見られただけでなく，共用空間の有無や併設事業所の 有無と家顀にも相関関係が見られた。継続居住の可能性と家顀との の関係に相関関係があるということである。これは一般の賃貸市場 とは異なる傾向である（通常の賃貸住宅市場では，家賃は個人空間 の充実度によって異なり，共用空間の違いは付加価值として加味さ れるに過ぎないという捉え方が支配的である)。住宅としてではな く，附帯サービスや継続居住方針を含めた住まい方として家顀が設 定されている状況が確認できた。

\section{(2)平面計画上の特性}

個人空間設備と共用空間の関係性から，「住戸十共用食堂」，「居室 十共用食堂」,「住戸十なし」の 3 つの居住モデルを導出した。この 居住モデルと, 運営主体, 利用者像, 併設機能などとの関連性を分 析した．クロス集計から一定の傾向が確認できたものの, 付帯サー ビスと利用者像から因子分析を行ったところ, 居住モデルと利用者 像・サービス附帯には明確な対応関係は確認できなかったが，共用 食堂なしの「住戸十なし」は, 共用食堂ありの「居室十共用食堂」「住 戸十共用食堂」とは異なる傾向にあった。

「住戸十共用食堂」と「居室十共用食堂」が同じ因子得点となっ たのは, 「住戸十共用食堂」で想定している幅広い利用者像を対象 としうるような経営モデルが見出しにくいためと推測された。一方, 「住戸＋なし」は中重度者向けの建築ではないため, 軽度者中心と なり, 見守り十地域に点在する介護系サービスで対応しているもの と推測した。

高専賃は制度化されて日も浅いため, 整備状況を確認しながら, 居住モデルの理念と実情の相違について改めて検討を行う必要があ ろう。その際には，家賃，共益費，基礎サービス費などの設定を明 確にしたうえで，高専顀と高優賃におけるサービス附帯の違いを含 めた分分析が欠かせない. 今後の課題としたい.

\section{謝辞}

本研究は平成 20 年度厚生労働省科学研究費補助金（政策科学総 合研究事業）による助成研究「市場性を備えた良質な高齢者住宅の 供給とケアサービスの附帯のさせ方に関する研究（H20 - 政策一一 般一 005)」の一環として行われた。財団アンケート調査は, 平成 20 年度厚生労働省健康増進事業として高齢者住宅財団が実施した。

注

注 1) 2009 年調べ。なお，養護老人ホーム：6.5 万戸，特定施設でないケア ハウス： 8.0 万戸，特定施設でない有料老人ホームについては，サービス 附帯の仕組みから高齢者向けの住宅と捉えることも可能だが, 厚生労働省 が所管していること, 養護老人ホームについては措置施設であることなど から，一般には施設として認識されている.

注 2) 高齢者専用賃貸住宅制度は 2005 年 12 月に施行.

注 3) 高専貢には建設費や家兵の補助が無く, 家貨や住戸を自由に設定できる. 注 4) 高優賃の基準は以下に示すものがある.

1. 各住戸の面積が $25 \mathrm{~m}^{2}$ 以上あること. 共同型(台所, 浴室等が共用の場合) の住戸は, $18 \mathrm{~m}^{2}$ 以上. 共同型でも, トイレ, 洗面設備のみは各住戸に備 えなければならない.

2。各住戸に必要な室内設備（台所，収納設備，水洗トイレ，洗面，浴室） を備えていること.
3．前払いで家賃を徵収する場合には保全措置を講ずること。

注 5) 除外した高齢者住宅は，一時金十前払い家賃の額が，300 万円 3,132 万円の 21 件である。これらは賃貸住宅とは趣旨が異なるため除外した。

注 6) この調査は, 高齢者住宅財団が平成 20 年度厚生労働省老健局健康增進 事業として実施したものであり, 共著者の井上が委員として調査研究に参 画した。アンケート調査は，配布 885 票，回収 399 票であった。

注 7) 整備割合とは, 各都道府県の高齢者住宅整備実数（戸数）を当該地域の 高㱓者数で除した割合である. 施設整備量に用いられる参酶標準などと比 較するために算出した。

注 8 ) 筆者らが平成 21 年度に東京都の全高専賃（含む高優顀 全 56 件）に対 して実施した調査によれば，回答を寄せた 35 件のうち 5 件で，見守りに 該当する基礎サービス費の全額を共益費に組み込んでいた。

注 9) 図は，ボックス・ウィスカー図を示している。図中の縃線の上端, 下端 は, 当該デー夕の最大值と最小值を示す。また線上の長方形の上端, 下端は, データの第 3 四分位点, 第 1 四分位点をそ扎ぞれ示し, 長方形内部の横線は, 中央值の位置を示す。それぞれに併記した值が，当該数值を示す。

注 10）面積（家顀）は, 高齢者住宅財団公表デー夕から面積下限值（家顀概 算下限值）を取得し，当該高齢者住宅の面積（家顀）とした。なお，デー 夕には面積上限值（家兵概算上限值）も記載されているが, 実際の高齢者 住宅では明示されている面積（家顀）の下限面積（家顀）の住宅が多く整 備されているとの調査実績に基づき, 面積下限值（家遉概算下限値）を面 積（家遉）として設定している.

注 11) 本来であれば共用空間の広さや食堂以外の諸設備を加味した分析が必 要であると考えるが, 財団登録デー夕には共用空間の広さの記載がなく, また食堂以外の共用空間設備の記載はサンプル数が極小であった。 そのた め共用空間に関しては, 共用食堂の有無のみを財団登録データから抽出し 分析を行っている。 また併設事業所（同一建物）の有無に関しては，次章 のアンケート調査結果を用いている. サンプル数は, 家顀と当該分析デー 夕が取得できたもののみであるため, 図表ごとに異なる.

注 12)「医療・介護系」に含まれる事業は, 病院, 介護サービス事業者, 介護 系 NPO 法人である。また「不動産・建設系」に含まれる事業は, 不動産販売・ 仲介・コンサルタント，建設業者（ゼネコン，施工・管理）である。なお， 複数の業種からなる運営主体は, その他に算入した。

\section{参考文献}

1) 厚生労働省 : 第 2 回介護施設等の在り方に関する委員会, 平成 18 年 12 月 15 日資料

2 ）スウェーデン社会省：Sweden Socialstyrelsen 資料

3 ）デンマーク社会省 : Denmark Socialministeriet 資料

4 ) Elderly Accommodation Counsel : the older population, 2004

5 ）医療経済研究機構：米国医療関連デー夕集，2005

6 ）内閣府：高粈者の住宅と生活環境に関する意識調査

7 ) 小野 信夫 : 高齢者専用賃貸住宅の現状と課題 -- 首都圈の高専賃登録デー 夕から考元る, ニッセイ基礎研究所，ニッセイ基礎研 report No.126, pp.19-26, 2007.9

8 ）松川修啓, 鈴木義弘:高優賃及び高専賃の類型的把握と計画課題について, 日本建築学会研究報告九州支部，No.46，pp.109-112，2007.3

9 ) 石井敏 : 入居者の居住実態からみた高踚者専用賃貸住宅のあり方に関す る事例考察, 日本建築学会計画系論文集，No.627，pp.963-969， 2008.5

10）熊澤暢子, 生田京子, 村上心, 山下哲郎：高龄者専用貢貸住宅の他用途 施設からの転用改修に関する研究，日本建築学会計画系論文集 No.633, pp.2317-2324, 2008.11

11）吉村直子：高龄者向け居住施設の現状と課題, 特集 高齢者居住の問題と 課題 -- 市場を通じた高齢期の安定した居住確保のために, 日本不動産学会 誌，No.79，pp.73-84，2007.12

12）不動産流通研究所：高専賃ビジネス成功のポイントと課題 徹底したマー ケティングを，編集部レポート 注目の高齢者専用賃貸住宅--そのビジネ ス手法を探る!, 月刊不動産流通，Vol.27, No.1, 2008.7

13）佐藤栄治, 井上由起子, 藤井賢一郎 : 高歯者住宅の整備状況をふま元 た家顀の現状分析, 日本介護経営学会学会誌, 介護経営, 第 4 巻第 1 号, pp.78-91，2009.11 